\title{
Correction
}

\section{Neuropsychiatric findings in anti-Ma2-positive paraneoplastic limbic encephalitis}

In the article "Neuropsychiatric findings in anti-Ma2-positive paraneoplastic limbic encephalitis" (Neurology 2003;61:1159-1160) by Scheid et al., J. Bauer, MD, should have been listed as a co-author. The author line should read as follows: "R. Scheid, MD; R. Voltz, MD; T. Guthke, PhD; J. Bauer, MD; D. Sammler; and D.Y. von Cramon, MD, PhD.” 


\section{Neurology}

\section{Neuropsychiatric findings in anti-Ma2-positive paraneoplastic limbic encephalitis}

Neurology 2003;61;1635

DOI 10.1212/WNL.61.11.1635

This information is current as of December 8, 2003

\section{Updated Information \&}

Services

Permissions \& Licensing

Reprints including high resolution figures, can be found at: http://n.neurology.org/content/61/11/1635.full

Information about reproducing this article in parts (figures,tables) or in its entirety can be found online at:

http://www.neurology.org/about/about_the_journal\#permissions

Information about ordering reprints can be found online:

http://n.neurology.org/subscribers/advertise

Neurology $®$ is the official journal of the American Academy of Neurology. Published continuously since 1951, it is now a weekly with 48 issues per year. Copyright . All rights reserved. Print ISSN: 0028-3878. Online ISSN: 1526-632X.

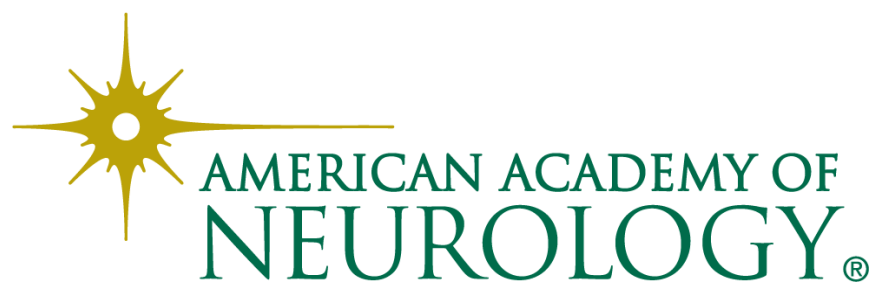

